\title{
Multispecies resource management of economically important marine plant communites of eastern Canada
}

\author{
J. D. Pringle \& G. J. Sharp \\ Fisheries and Oceans Canada, Marine Plants Section; Halifax, Nova Scotia, Canada
}

\begin{abstract}
The annual 45,000 tharvest of six marine plant taxa, consisting principally of the alga Chondrus crispus, is worth $\$ 5$ million annually to maritime fishermen. The harvesting techniques enable capture of associated biota and alter the abiotic structure of the habitat. Methods developed to assess ecological impact include permanent transects which are sampled for vegetation composition and dry biomass. C. crispus represents $80 \%$ of the plant biomass in commercial beds; 27 other genera comprise the remainder. Thirty-five associated invertebrate species include only one of direct economic importance, the lobster, Homarus americanus. On commercial Chondrus beds off western Prince Edward Island, lobsters were captured in basket dragrakes up to $5.4 \mathrm{~h}^{-1}$ during 1975 and 1976. Of the total lobster catch, the percentage injured by Chondrus dragrakes was $2.7 \%$ in 1975 and $1.3 \%$ in 1976. Chondrus dragrakes, as used in southwestern Nova Scotia, disrupt the drumlin. substrate. Controlled dragraking for 2 -h periods disrupted $0.25 \%$ to $1.5 \%$ of the bottom area. One month of normal harvest activity displaced $0.5 \%$ to $2.9 \%$ of the bottom of surveyed sites. A harvest of $1000 \mathrm{t}$ of Laminaria spp. is projected for 1979. Dragrakes harvest entire plants averaging $5.0 \pm 2.3 \mathrm{~m}$ in length. The residual population averaged $2.3 \pm 1.9 \mathrm{~m}$. Indirect effects of kelp harvesting on the benthic community are the subject of ongoing research.
\end{abstract}

\section{INTRODUCTION}

A mean annual harvest of 45,000 t (metric tons) of benthic marine algae, worth approximately $\$ 5$ million annually to the harvesters, is cropped from maritime waters. Six taxa have commercial value (Pringle, 1976); the most important is Chondrus crispus Stackhouse. Studies were initiated in 1975 to gather biological data deemed necessary to calculate optimum sustainable yield (OSY). Macrophyte harvesting includes a bycatch of closely associated biota (Pringle \& Semple, 1976). By cropping macrophytes, a layer of the physical habitat is removed. Perturbation of the substrate also occurs through the movement of the harvesting implement (MacFarlane, 1968; Pringle, 1979). Studies designed to assess quantitatively the effects of benthic algal harvesting on the associated organisms were initiated as eastern Canada has a rich inshore fishery and it is important that one fishery should not deleteriously affect another. Presented below are certain of the methods developed or adopted to assess and monitor both the short- and long-term effects of Chondrus and Laminaria harvesting on associated organisms. 


\section{RESULTS AND DISCUSSION}

\section{Permanent transects}

A program was initiated in 1975 to monitor the long-term effects of Chondrus harvesting on both the target species and associated organisms. The method developed is similar to that of Taylor (1973). It includes the point transect method, 1-m quadrats and lead line marked every $10 \mathrm{~m}$. The transects are run through the beds vertical to the shore, the angle determined with a surveying transit and noted for future reference. The transect bases are marked with a permanent bench mark cemented into the shore. In the southern Gulf of St. Lawrence, the vegetation cover and animal number are subjectively assessed every $10 \mathrm{~m}$ along the transect as is the substrate type. Every $50 \mathrm{~m}$ (this distance is arbitrary and depends on the width of the bed) either a $0.25-\mathrm{m}^{2}$ or $1-\mathrm{m}^{2}$ quadrat is placed and the vegetation removed, sorted to species, and the most abundant taxa dryweighed separately (Fig. 1). The sea urchins (Strongylocentrotus droebachiensis) and

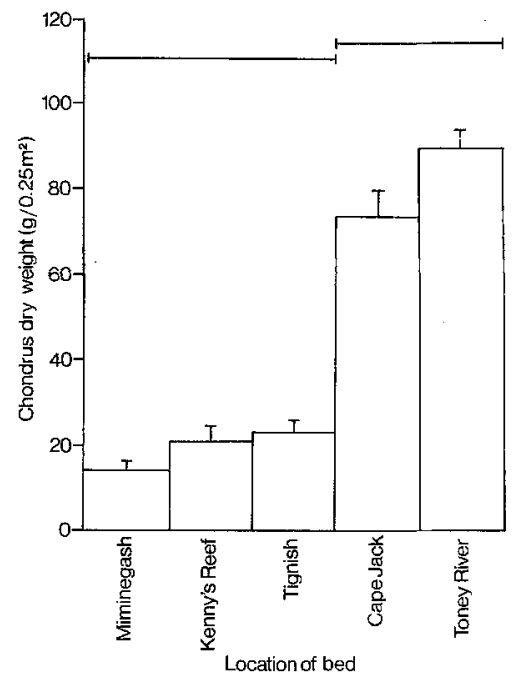

Fig. 1. The dry weight of Chondrus $\left(\mathrm{g} / 0.25 \mathrm{~m}^{2}\right)$ in various beds in the Gulf of St. Lawrence. Vertical lines represent standard error of the mean; horizontal lines represent Duncan's range test significant levels $(P<0.05)$

snails (predominantly Littorina spp.) within each quadrat are counted (Figs 2 and 3). At least three transects/bed are assessed. A program is underway to assess at least one commercially important bed per Marine Plant Harvesting District (Fig. 4) in this fashion. Similar data are being collected in southwestern Nova Scotia (Pringle \& Semple, in press).

\section{Southern Gulf of St. Lawrence}

The substrate in commercial Chondrus beds in the southern Gulf of St. Lawrence consists of sandstone ledge, boulders, and gravel. Dragraking (Scarratt, 1972; Pringle, 1979) takes place in Marine Plant Harvesting Districts 1-2 and 5-9 (Fig. 4). In District 4, 


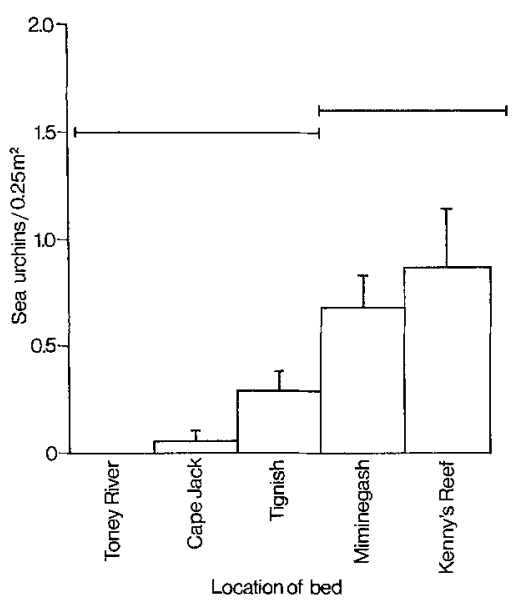

Fig. 2. The number of sea urchins (Strongylocentrotus droebachiensis) per $0.25 \mathrm{~m}^{2}$ in various Chondrus beds

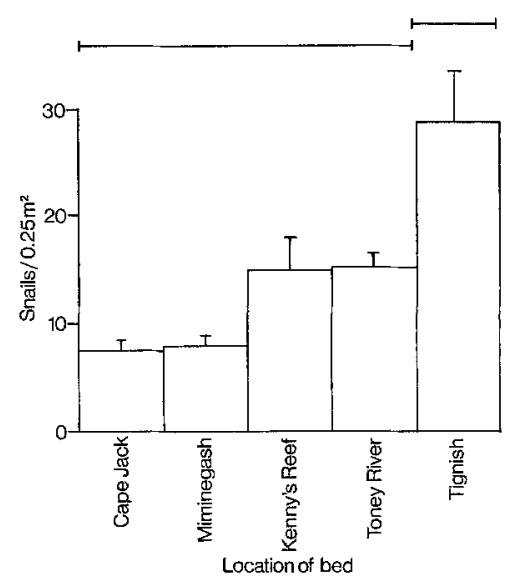

Fig. 3. The number of snails (Littorina spp.) per $0.25 \mathrm{~m}^{2}$ in various Chondrus beds

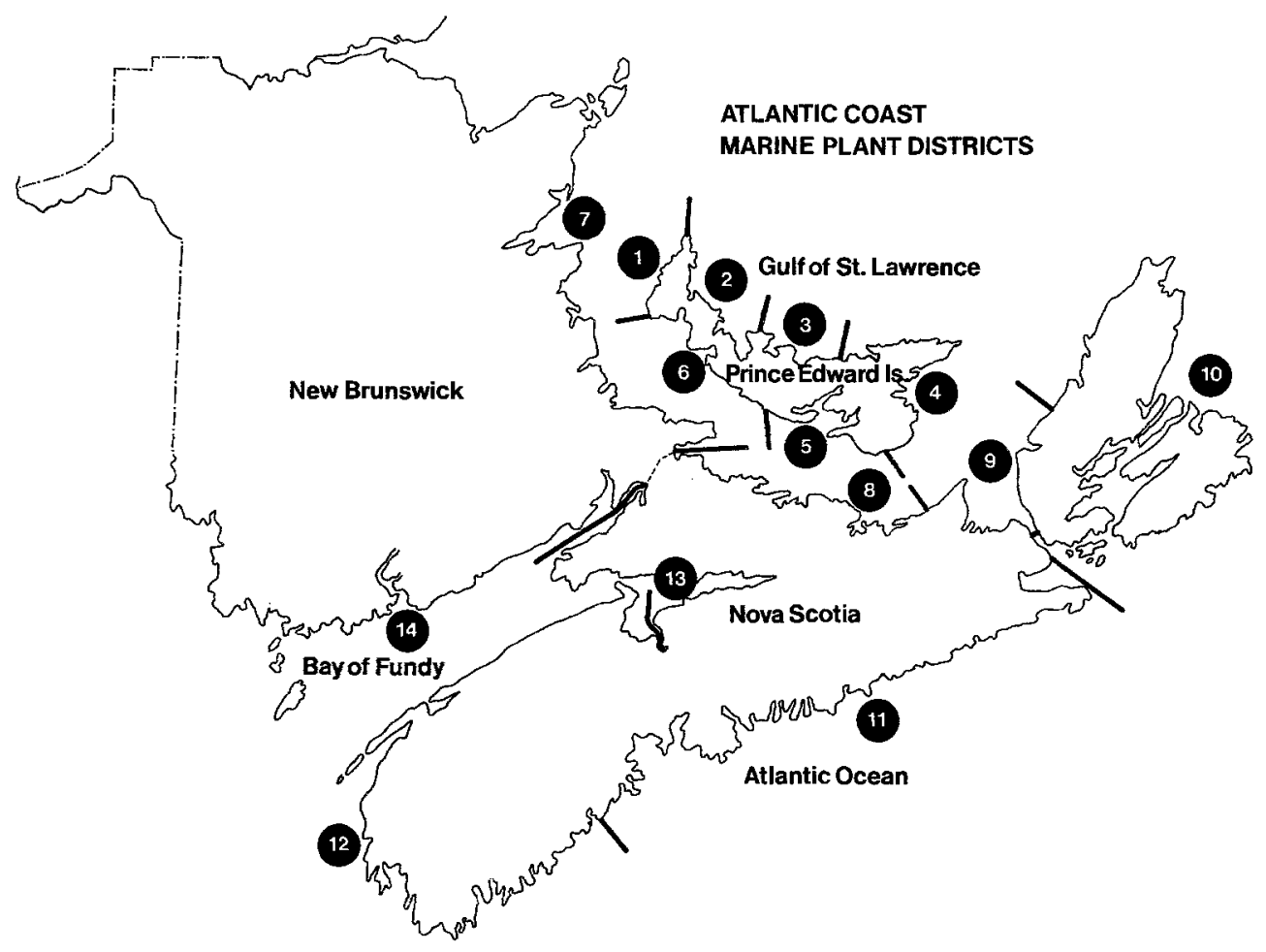

Fig. 4. The marine plant harvesting districts of the Maritime Provinces 
Chondrus is found in equal quantities with Furcellaria. Furcellaria will not withstand raking (C. I. MacFarlane, personal communication); consequently, dragraking was banned in the recently promulgated Atlantic Coast Marine Plant Harvesting Regulations in District 4 until a quantitative assessment of its effects on Furcellaria could be made.

In Districts 1 and 2, Chondrus has been raked for about 25 years. Recent studies have shown that Chondrus represents approximately $80 \%$ of the plant biomass in these beds (Fig. 5). The remaining biomass is made up of a minimum of 27 other genera (Table 1).
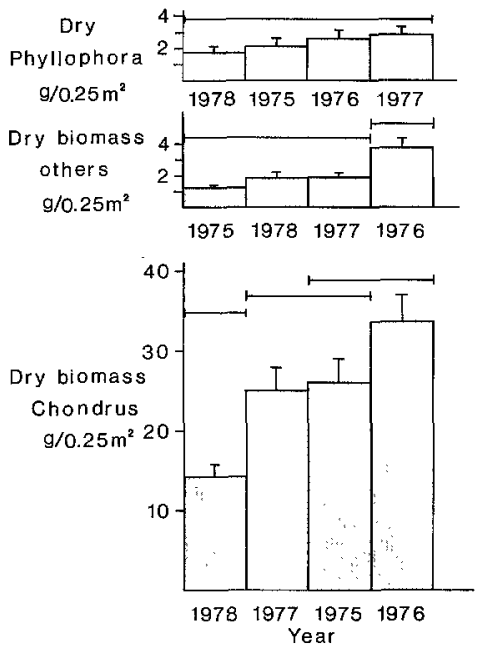

Fig. 5. The dry biomass of Chondrus, Phyllophora, and other marine plants per $0.25 \mathrm{~m}^{2}$ in a test bed off District 1 from 1975 to 1978

Chondrus has numerous animals associated with it (Lilly, 1968). Pringle and Semple (1976) observed 35 species from seven phyla in the crop from an experimental Chondrus harvester operating in Districts 3 and 6. Only one of these, the lobster Homarus americanus, is present in quantities sufficient to warrant commercial exploitation.

\section{Lobster impact}

To assess Chondrus harvesting technology and the ecological impact of both the dragrake and basket-dragrake on Chondrus and lobster in Districts 1 and 2, observers went on board harvesting boats for 101 harvest days during the harvesting seasons of 1975 and 1976 (Pringle, 1979). The number of lobsters captured in the basket-dragrakes or pierced by the tines of the dragrakes was noted, and each lobster was assessed for physical damage, i. e. missing appendages and damaged carapaces, etc. During this period, total harvesting effort was determined by counting the number of boats per bed on a daily basis.

The data for incidental lobster harvest for the 1975 and 1976 seasons for District 1 are given in Tables 2 and 3. Lobsters were captured at the rate of 1.0 and $0.53 \mathrm{~h}^{-1}$ in June of 1975 and 1976, respectively; this increased to 4.6 and $5.4 \mathrm{~h}^{-1}$ in July. The rate 
Table 1. Taxa observed in the 1975 Chondrus harvest of dragrakers from western Prince Edward Island and handrakers from southwestern Nova Scotia

\begin{tabular}{|c|c|c|c|c|}
\hline \multicolumn{2}{|c|}{ Taxa observed } & \multirow{2}{*}{$\begin{array}{l}\text { Southwest } \\
\text { Nova Scotia }\end{array}$} & \multirow{2}{*}{$\begin{array}{c}\text { Location } \\
\text { Miminegash } \\
\text { (District 1) }\end{array}$} & \multirow{2}{*}{$\begin{array}{c}\text { Tignish } \\
\text { (District 2) }\end{array}$} \\
\hline Tracheophyta & Zostera marina & & & \\
\hline \multirow[t]{4}{*}{ Chlorophyta } & Chaeotomorpha melagonium & $x$ & $x$ & \\
\hline & Cladophora spp. & $x$ & $x$ & $\times$ \\
\hline & Spongomorpha spp. & $x$ & $x$ & \\
\hline & Ulva lactuca & $x$ & $x$ & \\
\hline \multirow[t]{15}{*}{ Phaeophyta } & Acrothrix novae-angliae & $x$ & & \\
\hline & Ascophyllum nodosum & $x$ & & \\
\hline & Chorda filum & $x$ & $x$ & $x$ \\
\hline & Chordaria flagelliformis & $x$ & $x$ & $x$ \\
\hline & Desmarestia spp. & $x$ & $x$ & $x$ \\
\hline & Dictyosiphon spp. & $x$ & $\times$ & $x$ \\
\hline & Ectocarpus spp. & $x$ & $x$ & \\
\hline & Fucus spp. & $x$ & $x$ & $x$ \\
\hline & Halopteris scoparia & $x$ & $x$ & $x$ \\
\hline & Laminaria digitata & $x$ & $x$ & $x$ \\
\hline & Laminaria longicruris & $x$ & $x$ & $x$ \\
\hline & Punctaria spp. & $x$ & $x$ & $x$ \\
\hline & Pylaiella littoralis & $x$ & & \\
\hline & Saccorhiza dermatodea & $\times$ & $x$ & $x$ \\
\hline & Scytosiphon spp. & $x$ & $x$ & \\
\hline \multirow[t]{18}{*}{ Rhodophyta } & Ahnfeltia plicata & $x$ & $x$ & $x$ \\
\hline & Callophyllis cristata & $x$ & & \\
\hline & Ceramium spp. & $x$ & $x$ & \\
\hline & Chondrus crispus & $x$ & $x$ & $x$ \\
\hline & Corallina officinalis & $x$ & $x$ & $x$ \\
\hline & Cystoclonium purpureum & $x$ & & $x$ \\
\hline & Furcellaria lumbricalis & $x$ & $x$ & $x$ \\
\hline & Gigartina stellata & $x$ & & \\
\hline & Gloiosiphonia capillaris & $x$ & $x$ & \\
\hline & Lithothamnion spp. & $x$ & $x$ & $x$ \\
\hline & Phycodrys rubens & $x$ & & \\
\hline & Phyllophora spp. & $x$ & $x$ & $x$ \\
\hline & Polyides rotundus & $x$ & $x$ & $x$ \\
\hline & Polysiphonia spp. & $x$ & $x$ & $x$ \\
\hline & Porphyra spp. & $x$ & & \\
\hline & Ptilota serrata & $x$ & & \\
\hline & Rhodomela spp. & $x$ & $x$ & \\
\hline & Palmaria palmata & $\times$ & $x$ & \\
\hline
\end{tabular}

remained at this level through August. The percentage of lobsters injured was $13.4 \%$ and $4.0 \%$ in June of 1975 and 1976, respectively. The number of lobsters captured per hour was significantly higher in District 2 as was the incidence of lobster injury. The mean number of rocks returned per hour of harvesting per basket-dragrake in Districts 1 and 2 was 5.7 and 23, respectively. The increased frequency of boulders in District 2 probably accounted for the higher injury rates. 
Table 2. Estimated number of lobsters captured by the Chondrus harvesting fleet in Marine Plant Harvesting District 1-1975

\begin{tabular}{|lccccc|}
\hline Month & $\begin{array}{c}\text { No. of } \\
\text { harvesting } \\
\text { hours }\end{array}$ & $\begin{array}{c}\text { No. of lobsters } \\
\text { captured/hour } \\
\text { harvest }\end{array}$ & $\begin{array}{c}\text { Estimated no. } \\
\text { of lobsters } \\
\text { captured }\end{array}$ & $\begin{array}{c}\% \text { of captured } \\
\text { lobsters injured }\end{array}$ & $\begin{array}{c}\text { Estimated no. of } \\
\text { lobsters injured }\end{array}$ \\
\hline June & $11,572.0$ & 1.0 & $11,572.0$ & 13.4 & $1,550.7$ \\
July & $11,432.5$ & 4.6 & $52,589.5$ & 17.4 & $9,150.6$ \\
August & $3,837.9$ & 4.7 & $18,038.1$ & 12.9 & $2,326.9$ \\
Total & $26,842.4$ & & $82,199.6$ & & $13,028.2$ \\
\hline
\end{tabular}

Table 3. Estimated number of lobsters captured by the Chondrus harvesting fleet in Marine Plant Harvesting District $1-1976$

\begin{tabular}{|lccccc|}
\hline Month & $\begin{array}{c}\text { No. of } \\
\text { harvesting } \\
\text { hours }\end{array}$ & $\begin{array}{c}\text { No. of lobsters } \\
\text { captured/hour } \\
\text { harvest }\end{array}$ & $\begin{array}{c}\text { Estimated no. } \\
\text { of lobsters } \\
\text { captured }\end{array}$ & $\begin{array}{c}\% \text { of captured } \\
\text { lobsters injured }\end{array}$ & $\begin{array}{c}\text { Estimated no. of } \\
\text { lobsters injured }\end{array}$ \\
\hline June & $15,626.0$ & 0.53 & $8,281.8$ & 4.0 & 331.3 \\
July & $6,693.1$ & 5.4 & $36,142.7$ & 8.9 & $3,216,7$ \\
August & $1,789.8$ & 4.7 & $8,412.1$ & 28.7 & $2,414.3$ \\
Total & $24,108.9$ & & $52,836.6$ & & $5,962.3$ \\
\hline
\end{tabular}

Using the data (Tables 2 and 3), a crude estimate of the impact of Chondrus harvesting on the lobster fishery of District 1 was attempted. The numbers of trap-caught lobsters for 1975 and 1976 were 485,000 and 457,528, respectively (Table 4). The estimated numbers of incidentally caught lobsters by the Chondrus harvesting fleet in basket-dragrakes for these two years were $82,199.6$ and $52,836.6$ respectively. The percentages of Chondruscaught lobsters to trap-caught lobsters were $16.9 \%$ and $11.6 \%$ for 1975 and 1976 , respectively. The percentage of injured Chondrus-caught lobsters of the trap harvest was $2.7 \%$ in 1975 and $1.3 \%$ in 1976. The Chondrus landings for 1975 and 1976 were $7887 \mathrm{t}$ and $9500 \mathrm{t}$, respectively, which was worth approximately $\$ 700,000$ and $\$ 950,000$ for each respective year. Consequently, the loss in income to the lobster industry is more than compensated by the value of the Chondrus harvest. Scarratt (1972) came to a similar conclusion for District 3.

It is felt the above is only a rough estimate of the impact of Chondrus harvesting on the lobster fishery. To present a more accurate estimate, data would be required on the number of lobsters injured but not captured. Scarratt (1972) noted that the bulk of the lobster injuries caused by dragrakes occurred while the lobsters were under rocks in the track of the dragrake. To offset this underestimate of the impact on lobster are the following which tend to give an overestimate of the impact on lobsters: (1) the amount of lobster recapture in the basket-dragrakes is unknown; (2) the extent of the loss of lobsters through natural mortality; (3) it is likely not all the injuries to the lobsters were caused by the Chondrus harvesters (see Scarratt, 1972); and (4) the bulk of the injuries to the lobsters would not cause death. 
Table 4. An estimate of the percentage of injured Chondrus-caught lobsters to trap-caught lobsters off Marine Plant Harvesting District 1

\begin{tabular}{|cccccc|}
\hline Year & $\begin{array}{c}\text { Estimated no, } \\
\text { of trap-caught } \\
\text { lobsters }\end{array}$ & $\begin{array}{c}\text { Estimated no. of } \\
\text { Chondrus-caught } \\
\text { lobsters }\end{array}$ & $\begin{array}{c}\text { Percentage } \\
\text { Chondrus-caught } \\
\text { lobsters to } \\
\text { trap caught }\end{array}$ & $\begin{array}{c}\text { Estimated no.of } \\
\text { lobsters injured } \\
\text { in Chondrus } \\
\text { harvest }\end{array}$ & $\begin{array}{c}\text { Injured lobsters } \\
\text { as a percentage } \\
\text { of trap-caught }\end{array}$ \\
\hline 1975 & 485,000 & $82,199.6$ & 16.9 & $13,028.2$ & 2.7 \\
1976 & 457,528 & $52,836.6$ & 11.6 & $5,962.3$ & 1.3 \\
\hline
\end{tabular}

Indirect evidence that Chondrus harvesting has a minimal impact on the lobster fishery can be acquired by comparing lobster landings between districts where Chondrus harvesting does and does not take place. For example, in District 1 where dragraking is heavy, the lobster landings have increased $86 \%$ in the past ten years. Conversely, in District 3 where dragraking for Chondrus does not take place, lobster landings have increased by only $34 \%$ in the same period.

The use of basket-dragrakes, particularly in rocky areas such as District 2, results in a marked increase in the number of injured lobsters. Many are crushed by the captured rocks. For this reason and due to its impact on the Chondrus resource the basketdragrake has been banned through federal regulations.

\section{Dragraking in southwestern Nova Scotia}

A modified form of Chondrus dragraking as practised in Prince Edward Island is used in southwestern Nova Scotia (Pringle, 1979). This method of harvest extends the daily harvesting period and enables the harvesting of Chondrus beds below the reach of handrakes.

In Chondrus beds off southwestern Nova Scotia the drumlin substrate shows signs of disruption. This disruption is characterized by rocks with bare surfaces or with the upward surface bearing dark, anerobic silt and/or cryptic sessile, invertebrate species. Furthermore, a number of rocks are found with pioneer species such as Scytosiphon spp., Chorda spp., young Laminaria sporophytes, and Fucus sp.

Two methods were developed to assess the impact of dragraking. First, prior to the harvesting season, two sites with dissimilar wave exposure were selected for test raking. Plots $20 \mathrm{~m}$ by $10 \mathrm{~m}$ were outlined and dragraked for $2 \mathrm{~h}$. The number of displaced rocks was counted and maximum dimensions were measured, which fell on either side of a series of parallel transects. At a third site, closed to harvesting for the season, dragraking was carried on for four 2 - $h$ periods. The site was resurveyed after every $2 \mathrm{~h}$ of dragraking.

Test raking at a semi-sheltered site displaced 34 rocks ranging from $125 \mathrm{~cm}^{2}$ to $996 \mathrm{~cm}^{2}$ in area, totalling $1.5 \%$ of the bottom area during the removal of $54.75 \mathrm{~kg}$ of Chondrus. At a semi-exposed site, 15 rocks were moved while $118 \mathrm{~kg}$ of Chondrus was dragraked, displacing $0.25 \%$ of the bottom area. Examination of a semi-sheltered site after successive 2 -h dragraking trials showed bottom perturbation was cumulative within the limits of this experiment (Table 5). 
Table 5. Bottom perturbation - Lears Island test site after 2, 4, 6 and 8 hours dragraking

\begin{tabular}{|cccccc|}
\hline $\begin{array}{c}\text { Cumulative } \\
\text { total hours } \\
\text { dragging }\end{array}$ & $\begin{array}{c}\text { Number } \\
\text { of tows }\end{array}$ & $\begin{array}{c}\text { Chondrus } \\
(\mathrm{kg})\end{array}$ & $\begin{array}{c}\text { Cumulative } \\
\text { total rocks } \\
\text { displaced }\end{array}$ & $\begin{array}{c}\text { Surface } \\
\text { area of rocks } \\
\text { displaced } \mathrm{m}^{2}\end{array}$ & $\begin{array}{c}\text { Cumulative } \\
\text { \% of total } \\
\text { bottom area }\end{array}$ \\
\hline & 32 & 49 & 21 & 1.7 & 0.60 \\
4 & 28 & 47 & 43 & 2.2 & 0.80 \\
6 & 27 & 52 & 52 & 2.9 & 1.20 \\
8 & 39 & 58 & 58 & 3.1 & 1.25 \\
\hline$\Sigma$ & 126 & 167 & 58 & 3.1 & 1.25 \\
\hline
\end{tabular}

Secondly, during the harvest season the use of dragrakes was monitored on Chondrus beds during 30 tides. At heavily dragraked sites, four strip transects $1 \mathrm{~m}$ wide and $10 \mathrm{~m}$ apart were established perpendicular to the shoreline $10 \mathrm{~m}$ between the lower limit of both Ascophyllum nodosum and Chondrus. The area of displaced rocks was recorded with these strip transects monthly throughout the summer.

At sites where harvesting was monitored and surveyed, bottom disturbance appeared to be directly related to effort. One month of effort had the following effect on two semi-exposed sites: Site $1,0.53$ dragrakers per observation period resulted in $0.5 \pm 0.4 \%$ of the substrate area being displaced; Site $2,1.5$ dragrakers per observation period displaced $2.9 \pm 1.0 \%$ of the bottom area.

Substrate perturbation caused by dragraking has a multiple effect on the benthic community: Chondrus and other macrophytes are destroyed by covering; sessile and cryptic invertebrates are open to predation on the rock surface and the underlying substrate; and disruption of the habitat of motile invertebrates occurs.

\section{Laminaria harvesting}

A harvest of $1000 \mathrm{t}$ (wet weight) of Laminaria spp. is projected for 1979 from southwestern Nova Scotia for dried food stuffs. This tonnage could markedly increase due to a renewed interest in Laminaria spp. for alginate production (B. MacConnell, personal communication). The present method of harvesting is identical to the dragrake method used between 1942 and 1949 to harvest $5500 \mathrm{t}$ (wet weight) per year (Sharp, in press).

To assess the impact of the harvest method on the kelp beds, the following procedure was used: two plants were removed from each tow of the dragrake to determine species, length, and wet weight. Divers observed the dragrake track and demarcated it by dropping lead-weighted markers. This guided the placement of a $40-\mathrm{m}$ transect line. Every $5 \mathrm{~m}$ along this line $1-\mathrm{m}^{2}$ quadrats were placed and all Laminaria within was removed for length and weight measurement.

The kelp beds in southwestern Nova Scotia frequently contain an understory of $L$. digitata (L.) Lamouraux. The present harvest, however, consists of $98 \%$ L. longicruris removed as whole plants; occasionally the stipe or blade breaks before the holdfast. The dragraking method removed the larger plants in the population of which the mean total length was $5.02 \pm 2.3 \mathrm{~m}$ (Fig. $6 \mathrm{~A}$ ). The bulk of the plants less than $1 \mathrm{~m}$ in length in the 


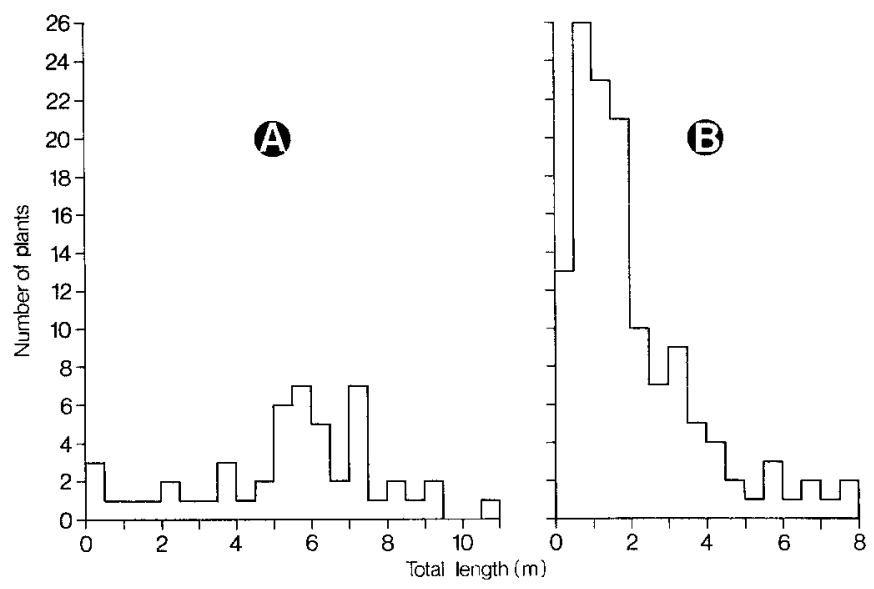

Fig. 6. The population structure (total length) of Laminaria longicruris. (A) Harvested plants, (B) remaining plants

harvest was entangled in the holdfasts of larger plants that were caught in the rake tines. The residual population averaged $2.3 \mathrm{~m} \pm 1.9 \mathrm{~m}$ in length (Fig. 6B). The biomass in the unharvested bed was $4.0 \pm 5.0 \mathrm{~kg} \mathrm{~m}^{-2}$; the harvested bed had $1.6 \pm 2.0 \mathrm{~kg} \mathrm{~m}^{2}$.

Bottom perturbation occurred particularly at the beginning of each tow when the drag contacted the bottom. Boulders up to $52 \mathrm{~cm}$ by $30 \mathrm{~cm}$ were displaced. Rocks averaging $7 \mathrm{~kg}$ attached to holdfasts were removed from the bottom.

The harvesting of Laminaria spp. removes a physical part of the habitat occupied by a number of benthic invertebrate and finfish species. It has been postulated that the loss of macrophyte cover due to grazing by $S$. droebachiensis correlates with the decline in $H$. americanus catch levels (Mann \& Breen, 1972).

The rate of linear blade growth in $L$. longicruris was recorded at up to $1 \mathrm{~cm} \mathrm{~d}^{-1}$ in this area (Chapman \& Gagne, in press). However, the dragraking method removes large numbers of entire plants; thus, recruitment of sporelings is required for the population to recover to its pre-harvest standing crop. At present, an economic CPUE (catch/unit effort) limit of $1.2 \mathrm{t} \mathrm{h}^{-1}$ exists for the dragraking method.

Harvesting of these kelp beds will be limited until the optimum sustainable yield (OSY) is known. The OSY for kelp could be beyond the minimum level of cover required for survival of kelp-dwelling fauna (Breen \& Mann, 1976). Various research groups in Nova Scotia have initiated studies in kelp beds as follows: the relative importance of kelp-bed invertebrates in the diet of $H$. americanus; the energy relationships in benthic invertebrate communities of kelp beds compared with barren ground communities; and the rate of recovery of standing crop in harvested kelp beds.

\section{CONCLUSION}

The studies introduced in this paper provide information to make long- and shortterm management decisions. Severely detrimental harvesting strategies can be identified and removed from the ecosystem immediately. Subtle effects on associated flora and fauna are detected in baseline studies. 
The development of management models for this complex flora and fauna association requires the filling of a large number of gaps in baseline data. These studies have shown that the harvesting of marine plants can affect every level of the inshore ecosystem, including the abiotic structure of the habitat.

Acknowledgements. The following students assisted in the various field programs: P. Blanchette, J. Booth, C. Doucette, C. Gaudey, R. Hall, D. McKenna, B. McLellan, B. MacNamara, D. MacRae, D. Roddick and D. Tremblay. B. Semple gave technical assistance and B. Hooper graciously helped the authors with algal taxonomy.

\section{LITERATURE CITED}

Chapman, A. R. O. \& Gagne, J. Environmental control of kelp growth in St. Margarets Bay and on the southwest shore of Nova Scotia. In: Proceedings of the workshop on the effects of commercial marine algal/animal harvesting on sea urchin grazing. Ed. by J. D. Pringle, G. J. Sharp \& J. F. Caddy. Fisheries and Oceans Canada, Halifax, N. S. (In press.)

Breen, P. A. \& Mann, K. H., 1976. Changing lobster abundance and destruction of kelp beds by sea urchins. - Mar. Biol. 34, 137-142.

Lilly, G. R., 1968. Some aspects of the ecology of Irish moss, Chondrus crispus (L.) Stackhouse in Newfoundland waters. - Tech. Rep. Fish. Res. Bd Can. 43, 1-44.

MacFarlane, C. I., 1952. A survey of certain seaweeds of commercial importance in Southwest Nova Scotia. - Can. J. Bot. 30, 78-97.

MacFarlane, C. I., 1968. Chondrus crispus Stackhouse - a synopsis. Nova Scotia Research Foundation, Halifax, N. S., 47 pp.

Mann, K. H. \& Breen, P. A., 1972. The relation between lobster abundance, sea urchins, and kelp beds. - J. Fish. Res. Bd Can. 29, 603-609.

Pringle, J. D., 1976. The marine plant industry - commercially important species and resource management. In: The proceedings of the Bras d'Or Lakes Aquaculture Conference. Ed. by G. McKay \& K. McKay. College of Cape Breton Press, Sydney, N. S., 161-181.

Pringle, J. D., 1979. Aspects of the ecological impact of Chondrus crispus (Florideophyceae) harvesting in eastern Canada. - Int. Seaweed Symp. 9, 225-232.

Pringle, J. D. \& Semple, R. E., 1976. A preliminary assessment of the ecological impact of an experimental Chondrus (Irish moss) harvester off coastal Prince Edward Island. - Fish. mar. Serv. tech. Rep. Ser. Mar/T-76/1, 1-28.

Pringle, J. D. \& Semple, R. E., 1978. The incidental harvest of immature Chondrus crispus (Irish moss) and its possible effects on commercial yield. - Tech. Rep. Fish. mar. Serv. 806, 1-7.

Pringle, J. D. \& Semple, R. E. The benthic algal biomass, commercial harvesting, and Chondrus growth on colonization off southwest Nova Scotia. In: Proceedings of the workshop on the effects of commercial marine algal/animal harvesting on sea urchin grazing. Ed. by J. D. Pringle, G. J. Sharp \& J. F. Caddy. Fisheries and Oceans Canada, Halifax, N. S. (In press.)

Scarratt, D. J., 1972. Investigations into the effects on lobsters of raking Irish moss, 1970-71. - Tech. Rep. Fish. Res. Bd Can. 329, 1-20.

Scarratt, D. J., 1973. Claw loss and other wounds in commercially caught lobsters (Homarus americanus) - J. Fish. Res. Bd Can. 30, 1370-1373.

Sharp, G. J. The history of kelp harvesting in southwestern Nova Scotia. In: Proceedings of the workshop on the effects of commercial marine algal/animal harvesting on sea urchin grazing. Ed. by J. D. Pringle, G. J. Sharp \& J. F. Caddy. Fisheries and Oceans Canada, Halifax, N. S. (In press.)

Taylor, A. R. A., 1973. Studies of populations of Chondrus crispus (Irish moss) and Furcellaria fastigiata in Prince Edward Island waters during 1971. - Fish. mar. Serv. tech. Rep. Ser, ind. Dev. Branch, Canada 65, 1-109. 